\title{
Literature Defined by Language? Some Remarks on the Definition of Estonian Literature ${ }^{1}$
}

\author{
ANNELI KÕVAMEES
}

\begin{abstract}
In the era when multiculturalism is one of the key concepts and the relationship between foreign and own is shifting, the definition of national literature has been in the centre of discussions. In Estonia the issue has been raised most prominently in connection with the Estonian Russianlanguage writer Andrei Ivanov (born 1971) whose works have turned out to be difficult to classify. How to define Estonian literature? Is it a literature written in the Estonian language, literature written by Estonians, literature associated with Estonia or is it a literature written in Estonia? Especially small nations like Estonians tend to define one's identity according to the language spoken and ethnicity, not the citizenship. There are various significant shifts in Estonian literary history, for example, when the beginning of Estonian literature is discussed, then Baltic German authors are included but when the Estonian literature made by Estonians is born in the $19^{\text {th }}$ century, Baltic German literature disappears from Estonian literature, although Baltic German literature continued until the $20^{\text {th }}$ century. The aspect of value plays a significant role, as what is included or excluded in the literary history is associated with ideological choices. It is only recently that the inclusion of Baltic German literature into Estonian literature is taking place. The position of Estonian Russian literature has also shifted from rejection and periphery in the spotlight and the works by Andrei Ivanov have played a crucial role in that process. Taking the Estonian Russian-language literature and Baltic German literature as examples, the article addresses the question of defining (national) literature.
\end{abstract}

Keywords: Estonian literature; Estonian Russian literature; Baltic German literature; Andrei Ivanov

1 This study was supported by the Estonian Ministry of Education and Research (IUT 18-4), and by the European Union through the European Regional Development Fund (Centre of Excellence in Estonian Studies).

* Proceedings of the seminar "Speaking About Small Literatures in Their Own Language" held at the $21^{\text {st }}$ congress of the ICLA Vienna 2016. 
Literature Defined by Language? Some Remarks on the Definition of Estonian Literature

\section{Introduction}

The contemporary world is full of movement as everything moves: goods, ideas, people. This movement has brought about various changes, for example, due to the movement of refugees, Europe has found itself in a new situation, which has raised not only economic, political and financial issues but also existential questions as the European way of life is changing. The demographic situation has changed and continues to change, various nationalities can be found in the world metropolises, the shift from the monocultural and monolingual world to the multicultural and multilingual one is obvious. Therefore, more and more people have a 'hyphenated identity' and consequently one's national identity may not be as clear as before.

The same can be applied to the definition of national literature as in the era of hyphenated identities the relationship between foreign and own is shifting and the definition of national literature is also under question. (For example, over the last years, there have been discussions about the exact definition of Estonian literature. Is it a literature written in the Estonian language, literature written by Estonians, literature associated with Estonia or is it a literature written in Estonia?) It has been asked whether "thinking, working and teaching in terms of national literatures [has] become obsolete in today's globalized world of hyphenated languages, literatures and cultures?" (Biti 2014: 1). Actually, not only the definition of national literature is questioned but the definition of literature altogether is discussed. Information technology has opened new perspectives and created new forms of literature (e.g. blogs, Facebook, twitterature, cyber literature, etc.); these days everyone can be a writer and publish a book either on paper or online, therefore it may be said that writing and publishing has been democratized. It is also worth mentioning that at universities literature is often part of cultural studies, there are fewer and fewer classical chairs of (national) literature and literary studies include a wide range of topics previously not considered as being part of literary studies or belonging to the margins. ${ }^{2}$ It has been noted that to study the so-called pure literature is currently not in fashion (Hasselblatt 2015b: 198).

2 In Estonia the position of philology and its developments were discussed at the conference "Filoloogia lagunemine" (The disintegration of philology) held in February 2016 and followed by a special issue of the magazine Keel ja Kirjandus (No. 8-9/2016). The developments in the humanities in connection with the nation were also discussed in a special issue of the magazine Keel ja Kirjandus (Humanities and Nation, No. 1-2/2018). The Estonian Literary Museum concentrated on the aspect of nationalism and nation in the 8 th summer school of literary studies in 2018 . Thus it may be said that the issue is topical. 
KÕVAMEES

The following article addresses some aspects concerning the definition of Estonian literature by taking the most significant others in Estonian culture Baltic German and Estonian Russian literature (the term Estonian Russianlanguage literature is used as a synonym) as examples. ${ }^{3}$

\section{The Beginning of Estonian Literature and the Case of Baltic German Literature}

The beginning of Estonian literature is a vivid example of how the definition of literature can be broadened if necessary. It is a common practice in Estonian literary histories to start by naming everything associated with Estonia and Estonians: chronicles, various texts that mention Estonians or texts that contain words and phrases in the Estonian-language, e.g. The Chronicle of Henry of Livonia, The Chronicle of Livonia (1578) by Balthasar Russow, Wanradt-Koell catechism (1535), ${ }^{4}$ etc. The Estonian aspect is highlighted, although it may have had a marginal role in the writing as a whole. The idea is to gather together everything associated with Estonia and Estonians when addressing the beginning of Estonian literature. It has been noted that the classical Estonian literary history has appropriated and domesticated a number of practical texts ('tarbetekstid' in Estonian) like church registers, calendars and agricultural guidelines. ${ }^{5}$ It is assumed that everything that could be considered as the history of the Estonian language is part of the history of Estonian literature (Kaljundi 2007: 949, 951; see also Neithal 2004: 677).

Therefore, it may be said that literature in this case is defined broadly as everything written or printed; and it is a common practice in literary histories that everything associated with Estonia or everything in the Estonian-language is considered part of Estonian literature when the beginning of Estonian

3 I have previously discussed the issue of Estonian Russian literature in Kõvamees 2014, Kõvamees 2015 and Kõvamees 2016.

4 The first (partially) survived printed text containing Estonian. Named after its authors pastors Simon Wanradt and Johann Koell.

5 Linda Kaljundi has raised the question whether these should necessarily be analysed as source materials of literary history as these could instead be the sources of social and cultural history and cultural anthropology. These materials offer the possibility to study the social and symbolic dimensions of human activities, communication systems, everyday culture and behaviour, manners and values. By analysing these texts in the context of cultural history, these would not be only small steps on a long road to nation's high culture but part of cultural practises in the broadest sense, offering the ways of new interpretations (Kaljundi 2007: 949-950). 
Literature Defined by Language? Some Remarks on the Definition of Estonian Literature

literature is discussed. For example, already the author of the first Estonian literary history Kurze Geschichte der ehstnischen Literatur (1843-1844) Dietrich Heinrich Jürgenson (1804-1841), who has been called the builder of the foundation who established the most principal aspects (Liiv 2003: 1352), used the term 'literature' in a very broad sense. Literature (either a manuscript or a printed text) is 'a written word, a book' (in German Schrift) and the history of literature is the history of the written word or the history of all books (Neithal 2004: 678). The same applies to the majority of literary histories when the beginning of Estonian literature is discussed. The Estonian researcher Tiit Hennoste has noted that before the literature of the $19^{\text {th }}$ century we will not find much fiction in the Estonian literary histories as after the $19^{\text {th }}$ century we will find much non-fiction (Hennoste 2003a: 57). ${ }^{6}$ People's literature ('rahvakirjandus' in Estonian) and practical literature ('tarbekirjandus' in Estonian) disappear from literary history when the Estonian high literature is born in the second half of $19^{\text {th }}$ century (Kaljundi 2007: 948).

The beginning of Estonian literature is associated with (Baltic) German authors. Baltic Germans were since the $13^{\text {th }}$ century the ruling class in Estonia, a large number of them were the descendants of the crusaders who invaded the countries that are today known as Estonia and Latvia. The split between social classes was deep and the most important category in determining one's social class was the differentiation Deutsch and Undeutsch. Therefore, language also marked the difference in one's social status, climbing the social ladder meant Germanisation and the loss of one's ethnic identity. It has been noted that in Estonian culture the relationship between the upper class and peasantry was different from Western Europe as Estonian speakers did not have an upper class and different classes spoke different languages. In Estonian culture a problem had to be solved: who would write the new Estonian literature and which language would be used. At the beginning of the $19^{\text {th }}$ century, everything was possible as the new Estonian high literature could have been written in German by literate persons from the German-speaking middle-classes. These problems were solved by the national awakening when Estonians opted for the literary

6 Tiit Hennoste has also noted that Estonian literary history in the $19^{\text {th }}$ century European sense was born in the $20^{\text {th }}$ century. The foundation was laid by Estonian literary researcher Mihkel Kampmaa (1867-1943) whose Eesti kirjanduse peajooned (The Main Currents of Estonian Literature) (I-IV, 1912-1936) has a fundamental role. The others, most notably Estonian literary researcher Friedebert Tuglas (1886-1971), continued the work. Most significant works were published from the 1920s reaching canonical entirety in the 1930s as literary histories for schools (Hennoste 2018: 97). 
culture created in the Estonian-language and by the peasantry (Hennoste 2003b: 102).

Thus, in the second half of the $19^{\text {th }}$ century Estonian national literature created by Estonians in the Estonian language was born and Baltic German literature disappeared from the Estonian literary history, although it continued until the $20^{\text {th }}$ century. It has been seen as a question of value: Baltic German literature is used when it allows to construct a long history for Estonian literature, when it is no longer necessary, it is discarded (Hennoste 2003a: 58).? The Estonian researcher Jaan Undusk has noted that the dependence on Baltic German literature was withdrawn during the Young Estonia movement at the beginning of the $20^{\text {th }}$ century (Undusk 1992a: 583). The denial of the cultural phenomenon of Baltic Germans was an ideological pillar for Young Estonia and it marked the self-realisation of Estonian national literature (Undusk 1992b: 711). Therefore, it may be concluded that Estonian literature begins in the periphery, having been for a long time part of Baltic German literature in Estonian (Undusk 1999: 251) and growing gradually into literature made by Estonians in the Estonian language (Hennoste 2003b: 88), which forms the core of Estonian literature.

The more extensive inclusion of Baltic German literature into Estonian literature started in the 1990s; see e.g. the works by Liina Lukas and Jaan Undusk who also introduced the term 'maiskondlik kirjandus(kultuur)'. The aspect of cultural space was introduced: the works of literature are not born in a vacuum but are written, printed and read in a concrete geographical and historical space, in a certain cultural space (Lukas 2004: 538-539). According

In the article analysing the first Estonian literary history published in the re-independent Republic of Estonia Eesti kirjanduslugu (2001), Hennoste notes that the common folk has given itself aristocratic roots like a petit bourgeois who is looking for a possibility to add the title von to his/her name. In his opinion, Estonian literary history (Estonia with a small e) should start where it starts. When folklore is considered to be literature, then the history should start with it and depict its development and vanishing into the periphery of culture. Then the other process should be described, starting with the real beginning of Estonian literature, meaning the end of the 18th century when the literary works in Estonian meant for Estonians appear. The era of complexity at the beginning of the $19^{\text {th }}$ century when the language of the writer, text and addressee could twine in a complex way (e.g. the essays in Estonian for Germans by Masing or the works in Estonian for Estonians by Baltic German pastors) should be dealt with. It is also important to show from where and how came the Estonian literature in the narrower meaning of the term. How it started with translations and adaptations and moved towards original literature, finally reaching professional literature (Hennoste 2001: 1228). 
Literature Defined by Language? Some Remarks on the Definition of Estonian Literature

to that idea texts written in Estonian and German in this land belong together and they have to be analysed together (Lukas 2008: 29). It has been noted that "up to the second half of the 19th century, Estonian literature can be treated as an "extension" of Baltic German literature in the Estonian language. Texts written in this area in Estonian (resp. in Latvian) and in German belonged together and were the different-style branches of one and the same literature, depending on the addressee (irrespective of their origin) the bilingual authors had in mind" (Lukas 2012: 235). Lukas has also noted that the Estonian literary historian inevitably asks for the cultural history of the land when s/he has to answer the question: where is the beginning of Estonian literature? Is it the first text from this land, the first text in Estonian or the first text written by an Estonian? Does Estonian literature, and thus the Estonian written culture, begin with The Chronicle of Henry of Livonia which was written in Latin at the beginning of the $13^{\text {th }}$ century or with Carmen Alexandrinum (1637) in the Estonian-language written by a German Reiner Brockmann (1609-1647) or with a lamentation Oh! Ma waene Tarto Liin (1708) in Estonian by an Estonian called Käsu Hans? If Estonian literature starts with Carmen Alexandrinum then what to do with other texts by Brockmann written in the same year in German (a poem praising the Estonian language Lectori Carminis Esthonici) or in Latin (a poem praising the collection of sermons Leyen Spiegel (1641) in Estonian by Heinrich Stahl)? The researcher of Estonian literature inevitably faces the historical multilingual nature of this place and has to inquire after its context where the literary culture in the Estonian-language was born to understand why it was born. This context has usually been left aside by Estonian literary history (Lukas 2008: 23-24). On the other hand, it has been noted that a place-centred literary history is something different from the language-centred literary history or a history of a nation defined by language (Hennoste 2018: 100). It may be concluded that when defining Estonian literature the linguistic aspect has prevailed and its roots lead to the era of national awakening. This aspect has also made it difficult to comfortably classify the works of Estonian Russian writer Andrei Ivanov (born in 1971) as Estonian literature (Laanes, Monticelli 2017: 43).

\section{The Definition of Estonian Literature and the Case of Estonian Russian Literature}

When the more extensive inclusion and more complex treatment of the Baltic German literature into Estonian literature started in the 1990s, only at the beginning of the $21^{\text {st }}$ century has the Estonian literary criticism started to deal 
with the Estonian Russian-language literature as part of Estonian literature. It has been noted that before Andrei Ivanov entered the literary scene, there was a clear distinction between Estonian and Estonian Russian literature: Estonian literature is written in the Estonian language and Estonian Russian literature in Russian (Laanes, Monticelli 2017: 43).

The topic 'Russian-language writers and Estonia' has been divided into four periods: the Russian-language literary life in the Republic of Estonia (until 1940); the Russian-language writers in Soviet Estonia; the search for the roots of the Estonian Russian-language literature in the newly independent Estonia. The literary magazine Vikerkaar/Raduga (Rainbow) (established in 1986) was published in Estonian and in Russian and had a significant role in demolishing the Soviet era political, historical and artistic stereotypes. The beginning of the $21^{\text {st }}$ century marks the beginning of the new era: writers work with Estonian materials, co-operate with the Estonian-language colleagues, they are part of the Estonian literary system (The Estonian Writers Union, The Estonian Cultural Endowment, literary magazines, publishing companies). A bilingual (Estonian-Russian) literary society Tuulelohe (Kite) was born and contacts between Estonian and Russian writers are close (Kotjuh 2010: 134-135). The authors of the younger generation of Estonian Russian writers who emerged in the 2000s are the first to be considered part of Estonian literature (Kotjuh 2013: 68). The generation consists of authors born in the 1970s and 1980s who made their debut in literature in the 2000s, e.g. P. I. Filimonov (born in 1975), Deniss Kuzmin (born in 1981), Igor Kotjuh (born in 1978) and Andrei Ivanov (born in 1971) (Kotjuh 2013: 67). The beginning of the $21^{\text {st }}$ century marks the era of the principally new Estonian Russian literature created by the noughts generation. The authors are characterised by the following: they identify themselves with Estonia (most of them also speak Estonian) and, as noted above, managed to make contact with the Estonian-language writers, journalists and editors; they published their Russian language works in the internet and searched for publication possibilities in Estonia; they took care that their works were published in Estonian translation (Kotjuh 2013: 67).

The Russian-speaking authors of Estonia have always defined themselves as multicultural (Kotjuh 2013: 74) but "the reigning social-historical paradigm defines a person according to a single national-cultural identity" (Kotjuh 2013: 79), which has brought along some intriguing debates. The most well-known example is Andrei Ivanov ${ }^{8}$ whose books published in Estonian have initiated discussions about the definition of Estonian literature. It has been noted that

\footnotetext{
8 About him and his works see e.g. http://www.estlit.ee/elis/?cmd=writer\&id=55407.
} 
Literature Defined by Language? Some Remarks on the Definition of Estonian Literature

thanks to him the conception of Estonian-Russian literature has a new form and place (Laanes, Monticelli 2017: 41). The limitations of the Estonian literary prizes are also being debated (see e.g. Kõvamees 2014: 193-196; Kõvamees 2015: 84-86). In the context of this article the statement made in connection with the novel Peotäis porrmu (A Handful of Dust) (2011) by the chairman of the literary panel of the annual awards of the Cultural Endowment is relevant and worth repeating. "A Handful of Dust is not written in Estonian and was published as a translation from Russian into Estonian. ${ }^{9}$ That was the one and only reason why the jury did not even consider nominating the novel. Original writing and writing in translation are seen as principally different kinds of text" (Lotman 2012). The Estonian language offers the possibility to write "Estonian literature' with a capital letter ' $E$ ' or with a small letter and there is a difference in meaning, which was also noted by the chairman: "Estonian literature with a capital 'E' divides into Estonian literature and Estonian Russian literature. The first is written in Estonian and the second in Russian, for the first the Cultural Endowment has Estonian literature awards and for the second the award for the author writing in Russian. That is also the way the Institute of the Estonian Language and Estonian Literary Studies deals with the difference" (Lotman 2012). Therefore, already the polysemous nature of the Estonian-language itself leaves room for interpretation and the speaker has to specify whether s/ he means Estonia with a capital letter or with a small letter (Hasselblatt 2015b: 196).

Estonian literary history has usually been defined as the history of literature in Estonian and the language plays the most important role (Kaljundi 2007: 944). The author of the most recent Estonian literary history Geschichte der estnischen Literatur (2006, was published in Estonian in 2016) Cornelius Hasselblatt for example states that Estonian literature is synonymous to literature in the Estonian language (Hasselblatt 2015a: 26). Tiit Hennoste has also noted that the core of Estonian literature is certainly made by the Estonians in the Estonian language in Estonia and meant for the Estonianlanguage readers (Hennoste 2003a: 58). What have created discussions and raised questions are the peripheries of Estonian literature; and the case of Andrei Ivanov is one good example.

9 When the statement was made, the novel had not been published in Russian. The novel was translated into Estonian from the Russian manuscript. The novel was published in Russian in 2014. 


\section{Conclusion}

Literature plays an important role in the national identity; and what is included in the literary history or excluded is associated with ideological choices (Liiv 2003: 1351). The seemingly comprehensive histories of every period, region and culture are inevitably derived from the present, depending on the values of the era and the intentions and desires of creators (Kaljundi 2007: 938). One cannot deny the aspect of certain uneasiness concerning the Baltic Germans and Russians which has influenced the way their role has been seen in Estonian culture. The fact that especially the Baltic Germans were a ruling class in Estonia has strongly influenced the way their role in Estonian history and culture has been addressed. Nevertheless, it may be noted that recent decades have brought forward a more versatile approach to Estonian history, culture and literature, principals which were self-evident for a long time have been questioned and the role of the viewpoint from which (literary) history is written is emphasised. ${ }^{10}$

There is more than one way to define literature and there is more than one way to write literary histories. The issue of how to write literary history was for example discussed in 2007 in Nüpli spring school under the title "How to tell the history of literature?" (Laak 2007). The aspect of telling was foregrounded. It is possible to write literary histories from different viewpoints and language is one of the possibilities but not the only one. We may define Estonian literature as literature written in Estonian by Estonians and then we speak about Estonian literature with a small letter ('eesti kirjandus'). We may also define Estonian literature as literature written in Estonia and then we speak about Estonian literature with a capital 'E' ('Eesti kirjandus'). In the era where there are slogans like 'let's make Estonia bigger', there is also a possibility to include everything associated with Estonia as Estonian. The writer Enn Nou has noted: the definition and criteria of Estonian national literature should be set at the maximum, meaning to include everything that can be associated with the

10 When for example Eesti ajalugu II. Eesti keskaeg (Estonian History II. Estonian MiddleAge) (2012) was published, heated debates followed concerning the concept and terms used. One of the issues brought forward was the fact that the term 'muistne vabadusvõitlus' (ancient fight for freedom) was not used any more as the concept did not originate from the national-romantic point of view (see e.g. Bahovski 2013). The first Estonian literary history published in the independent Republic of Estonia Eesti kirjanduslugu (2001) was also followed by a large number of articles and discussions (see e.g. Kalda 2001). That allows to draw the conclusion that these questions (e.g. how historical event are interpreted, what is included in the literary canon, etc.) are important and interest wider audiences. 
Literature Defined by Language? Some Remarks on the Definition of Estonian Literature

Estonian language, nation, land, thinking and feelings (Nõu 1990: 84). ${ }^{11}$ There are various possibilities but it is important to establish one's position, principles and understanding of the terms used and be aware that there is more than one way to define national literature.

\author{
Anneli Kõvamees \\ anneli.kovamees@tlu.ee \\ Tallinna Ülikool \\ Humanitaarteaduste instituut \\ Narva mnt 29 \\ 10120 Tallinn \\ EESTI / ESTONIA
}

\title{
References
}

Bahovski, E. 2013. "Eesti ajalugu II" tähistab murrangut meie ajalookirjutuses. http://uudised.err.ee/v/eesti/e1432e64-3b22-4d50-938f-84fe20e26800 (17.08. 2016)

Biti, V. 2014. Introduction. - V. Biti (ed.) Reexamining the National-Philological Legacy. Quest for a New Paradigm? Studia Imagologica 22. Amsterdam, New York: Rodopi, p. 1-21.

Hasselblatt, C. 2015a. Rahvuskultuuri paradoks ning eesti keele tähtsus. - C. Hasselblatt, Eemalt vaadates. Tartu: Tartu Ülikooli kirjastus, p. 26-33.

Hasselblatt, C. 2015b. Eesti kirjandusteaduse „Kes? Mis? Kus?“. - C. Hasselblatt, Eemalt vaadates. Tartu: Tartu Ülikooli kirjastus, p.196-209.

Hennoste, T. 2001. Probleemid ja onnestumised. 1+4 vaadet uuele kirjandusloole. Looming, No. 8, p. 1226-1239.

Hennoste, T. 2003a. Kirjanduse periodiseerimisest. I. Taustast ja teooriast. - T. Hennoste, Eurooplaseks saamine. Tartu: Tartu Ülikooli kirjastus, p. 57-85.

Hennoste, T. 2003b. Kirjanduse periodiseerimisest. II. Eesti asi. - T. Hennoste, Eurooplaseks saamine. Tartu: Tartu Ülikooli kirjastus, p. 86-107.

Hennoste, T. 2018. Kirjandus, teadus ja rahvus. - Keel ja Kirjandus, No. 1-2, p. 92-103. Kalda, M. 2001. "Eesti kirjanduslugu” kriitikute risttules. - Keel ja Kirjandus, No. 12, p. $868-871$.

Kaljundi, L. 2007. Kirjandus(aja)looline Eesti. - Keel ja Kirjandus, No. 12, p. 937-953. Kotjuh, I. 2010. Eesti venekeelne kirjandus: kas osa eesti või vene kirjandusest? - Keel ja Kirjandus, No. 2, p. 134-139.

11 Jüri Talvet has also noted that when defining the nationalliterature, setting the language criterion to the absolute maximum would lead to the questionable self-limitation. Although, national language will remain the main carrier of national literature, its liveliness and esthetical full value (Talvet 1990: 27). 
KÕVAMEES

Kotjuh, I. 2013. Eesti venekeelse kirjanduse nullindate põlvkond: vastuvõtt ja tõrked omaks tunnistamisel. - Methis, No. 11, p. 64-83.

Kõvamees, A. 2014. "A Handful of Dust": the Case of Estonian Russians and Existential Outsiderness. - Interlitteraria 19/1, p. 193-201. DOI: http://dx.doi. org/10.12697/IL.2014.19.1.14

Kõvamees, A. 2015. Out of the Unknown and into the Limelight: The Case of Estonian Russian Literature. - Interlitteraria 20/1, p. 83-93. DOI: http://dx.doi. org/10.12697/IL.2015.20.1.7

Kõvamees, A. 2016. Found in Translation: The Reception of Andrei Ivanov's Prose in Estonia. - Interlitteraria 21/1, p. 95-106. DOI: http://dx.doi.org/10.12697/ IL.2016.21.1.8

Laak, M. 2007. Kuidas jutustada kirjanduse ajalugu. - Keel ja Kirjandus, No. 10, p. $848-851$.

Laanes, E., Monticelli, D. 2017. Mittekuulumise valu ja võimalus. Andrei Ivanovi erand eesti kirjanduses. - Keel ja Kirjandus, No. 1, p. 41-57.

Liiv, T. 2003. Eesti kirjanduslugudest XIX sajandil. - Looming, No. 9, p. 1350-1360.

Lotman, R. 2012. Milleks õhutada vaenu tühja koha pealt? - Sirp, 2.03.

Lukas, L. 2004. Läbielatud ruum? Lisandusi baltisaksa kirjandusloo uurimisse. Akadeemia, No. 3, p. 531-561.

Lukas, L. 2008. Balti kirjakultuuri mitmekeelsest loomust. - R. Undusk (ed.) Rahvuskultuur ja tema teised. Collegium litterarum 22. Tallinn: Underi ja Tuglase Kirjanduskeskus, p. 23-33.

Lukas, L. 2012. The Shifting Position of German Literature in the Estonian Canon of World Literature. - Interlitteraria, Vol.17, p. 225-240.

Neithal, R. 2004. Eesti kirjandusloo lätetel. 200 aastat D. H. Jürgensoni sünnist. - Keel ja Kirjandus, No. 9, p. 670-680.

Nõu, E. 1990. Rahvuskirjanduse mõiste ja kriteeriumid eesti kirjanduse paigalepanekul. - Kõnelusi rahvuskirjandusest. Collegium litterarum 1, Tallinn: ETA, KKI, p. $80-85$.

Talvet, J. 1990. Rahvuskirjanduse orientatsioonist ja väärtustusest. - J. Undusk, P. Viires (eds.) Kõnelusi rahvuskirjandusest. Collegium litterarum 2, Tallinn: ETA, KKI, p. 27-29.

Undusk, J. 1992a. Saksa-eesti kirjandussuhete tüpoloogia. - Keel ja Kirjandus, No. 10, p. 583-594.

Undusk, J. 1992b. Saksa-eesti kirjandussuhete tüpoloogia. - Keel ja Kirjandus, No. 12, p. 709-725.

Undusk, J. 1999. Eesti kirjanduse ajast, ruumist ja ülesandest XX sajandil. - Looming, No. 2, p. 249-255. 